\title{
Introduction and Biography
}

\author{
Joshua Byron Smith
}

Geoffrey of Monmouth has suffered a glorious indignity that few writers have ever achieved: his creation has completely outstripped the maker. Few members of the general public, even well-educated ones, recognize the name Geoffrey of Monmouth. (A fact that the personal experience of this chatty medievalist has confirmed on numerous awkward occasions). But his creation is another matter altogether. The names of King Arthur, Guinevere, and their attendant knights perk up the ears of taxi drivers, coal mining fathers and grandfathers, and even scholars of contemporary literature. Medievalists, though we may know Geoffrey's name, have found him hard to contain and classify. So far-ranging is Geoffrey's work that he falls under the purview of several scholarly fields, many of which remain relatively isolated from one another: folklore, history, romance, manuscript studies, Celtic studies, classical reception, and medieval Latin - not to mention the seemingly endless expanse of Geoffrey's Nachleben, with its parade of translations, adaptations, and inspirations that continues to the present day. This volume aims to bring together, for the first time, many of these fields and to offer something close to a comprehensive overview of Geoffrey's life and work. It is our hope that this volume will serve as a current snapshot of Galfridian scholarship, incite more interest in Geoffrey and his work, and bring his artistry into greater prominence, all of which - if one is allowed to dream - might ultimately lead to slightly fewer blank stares for some of us.

Geoffrey's fame rests on three Latin works, the earliest of which is the Prophetiae Merlini ("The Prophecies of Merlin", hereafter abbreviated PM), a collection of prophecies completed before Henry I's death in $1135 .{ }^{1}$ With baroque animalistic imagery and apocalyptic fervor, its meaning sometimes seems transparent, and yet at other times playfully obscure. Over 8o copies of this text survive, and it inspired a vogue for Merlin's prophecies throughout

1 Orderic Vitalis, EcclesiasticalHistoryxii.47 (iv.486), ed. and trans. M.Chibnall, The Ecclesiastical History of Orderic Vitalis, 6 vols., Oxford, 1969-8o, vol. 6, p. 381. See also Tahkokallio's contribution to this volume. Some of the research for this chapter was presented at the 9 th Bangor Colloquium on Medieval Wales on 20 October 2018; I would like to thank the organizers and participants for their helpful discussion on several aspects of this chapter, especially Huw Pryce. 
Europe. ${ }^{2}$ Geoffrey included the $P M$ in his next work, the De gestis Britonum ("On the Deeds of the Britons", hereafter abbreviated $D G B$ ). He had finished this work by January 1139 at the latest, when Henry of Huntingdon reports his astonishment at finding a copy at the abbey of Le Bec. ${ }^{3}$ The count of surviving medieval manuscripts of the $D G B$ is now 225, making Geoffrey one of the most widely-read secular authors from medieval Britain. ${ }^{4}$ Yet even this impressive tally of extant manuscripts falls short of showing the work's reception. The $D G B$ was adapted, abbreviated, and translated again and again, making it one of the most influential works of medieval European literature. Its appeal arises from several factors. It filled a gap in the historical record by providing a full account of the earliest history of Britain, from the settlement of the island until the time of the Anglo-Saxon invasion. It also gave the first thorough picture of King Arthur, whose court and conquests are described in such extravagant detail that they inspired generations of future writers. It placed Britain on par with ancient Greece and Rome and made the Britons major players in classical history. Finally, Geoffrey's skill as a writer and his sheer inventiveness make the $D G B$ a pleasurable read. Even bare lists of kings are regularly punctuated with marvelous anecdotes.

Until recently, Geoffrey's history was called the Historia regum Britanniae ("The History of the Kings of Britain"), but Michael D. Reeve's textual study has confirmed that the title used in the earliest manuscripts, and by Geoffrey himself, was the De gestis Britonum. ${ }^{5}$ After much debate among contributors, this volume begins the lugubrious process of using the original title in place of the received one. Aside from a desire for greater accuracy, the change is helpful in identifying references to Geoffrey's text and in showing how he framed his own project: the difference between British "deeds" (gesta) and British "kings" (reges) is not insignificant and shows that Geoffrey conceptualized his own work as being equal to the other great historical works with de gestis in their titles. Furthermore, Geoffrey's focus on a people (Britons) instead of a transferrable geopolitical area (Britannia) surely bears on critical discussions of Geoffrey's aims in writing his work. Indeed, the emergence of the alternative title might even suggest that many medieval readers viewed his history as providing Britain, not the Welsh, with an ancient, respectable past. Geoffrey's

2 For a list of $P M$ manuscripts, see Crick, $S C$, pp. 330-32. See also Tahkokallio's contribution to this volume.

3 See Henry of Huntingdon, History of the English Letter to Warin, ed. and trans. D. Greenway, Henry, Archdeacon of Huntingdon: Historia Anglorum. The History of the English People, Oxford, 1996, pp. 558-83. See also Tahkokallio's and Meecham-Jones's contributions to this volume.

4 Crick, $S C$. For an updated survey, see Tahkokallio's contribution to this volume.

$5 \quad D G B$, p. lix. 
third and final extant work is the Vita Merlini ("The Life of Merlin", hereafter abbreviated $V M$ ), completed around $115 \mathrm{o}$ and extant in only four independent manuscripts. ${ }^{6}$ Written in dactylic hexameter, this poem recounts how Merlin Silvester goes mad after battle and retires to the woods to live; this enigmatic and difficult work seems to be deeply in touch with Welsh literature, though its ultimate sources are unknown. Taken together, Geoffrey's literary output shows him to be a versatile author: a master of verse and prose, capable of writing forceful speeches and enigmatic prophecy, and a voracious reader and researcher. Although he claimed to be nothing more than a translator - thereby conforming to medieval literature's aversion to originality, at least outwardly he remains one of the most strikingly original writers of the Middle Ages.

A Companion to Geoffrey of Monmouth introduces Geoffrey's oeuvre to firsttime readers and provides a synthesis of current scholarship, all while offering new readings of his work. This volume also seeks to bring Celtic studies and Galfridian studies into closer dialogue, especially given the importance of Wales to Geoffrey and his work. To that end, many of the essays are written by specialists in Welsh history and literature, whose voices have at times been hard to discern in the general din of Galfridian scholarship. We have also asked contributors to focus on all of Geoffrey's work, and not merely the Arthurian sections. Geoffrey has been well-served by Arthurian scholarship, and we have no desire to replicate many of the excellent recent studies in that field. ${ }^{7}$ Instead, we hope a holistic approach to his work will reveal subtleties often overlooked in scholarship that concentrates primarily on the Arthurian portions.

The volume is loosely divided into four parts: "Sources", "Contemporary Contexts", "Approaches", and "Reception". Ben Guy begins the first part with an investigation of Geoffrey's Welsh sources, showing that Geoffrey not only acquired but also understood a wide array of Welsh texts. Classical sources are examined by Paul Russell, who investigates Geoffrey's classical and biblical references, many of which are glancing and difficult to detect. Rebecca Thomas deals with Geoffrey's early English sources, which he often undermines through his own sleights of hand. Maud Burnett McInerney rounds off this section by demonstrating that Geoffrey learned how to cultivate prophetic ambiguity in the $P M$ through careful study of his sources, especially Virgil. Taken as a whole, these chapters show that Geoffrey was an avid researcher,

6 Crick, $S C$, p. 333. The $V M$ is also found inserted into four copies of Ranulph Higden's Polychronicon; see VM, pp. 43-44. See also McInerney's contribution to this volume.

7 For example, see the series Arthurian Literature in the Middle Ages published by the University of Wales Press and S. Echard, Arthurian Literature and the Latin Tradition (Cambridge Studies in Medieval Literature, 36), Cambridge, 1998, esp. pp. 31-67. 
read his sources with discretion, and could manipulate them better than many of his contemporaries.

The next part, "Contemporary Contexts", provides historical and cultural contexts for Geoffrey's work. Jaakko Tahkokallio's chapter surveys the early dissemination of Geoffrey's manuscripts and offers valuable new insights on networks of dissemination, Geoffrey's patrons, and his readership. A few of those early readers are the topic of Simon Meecham-Jones's chapter, which reevaluates early negative reactions to Geoffrey's history. There were, he argues, good reasons for these readers to affect a dislike of the $D G B$. Siân Echard, on the other hand, discusses Geoffrey's Latin readers, many of whom enjoyed his work so much that they felt compelled to interact with the text at length. Françoise Le Saux tackles the difficult question of Geoffrey's influence on the nascent genre of romance, showing how French-language writers quickly took to his work. Welsh speakers, too, also read Geoffrey's work with deep interest, and this Welsh reception is the subject of Owain Wyn Jones's chapter, which demonstrates how his history fits into Welsh historiography. On the other side of the border, Georgia Henley's chapter shows that Geoffrey's work, which is usually seen as an outlier in Anglo-Norman historical writing, actively engages with 12th-century historical methodologies. Wide-ranging and varied, these chapters nonetheless cohere to show Geoffrey's work as both a product of its culture and a cultural force in its own right.

The penultimate part, "Approaches", highlights the dominant trends in Galfridian scholarship and provides a platform for several critical approaches to his work, focusing particularly on Geoffrey's importance to postcolonial theory, feminist theory, critical race theory, and religious studies. Perhaps the most dominant trend in Galfridian scholarship, especially in the past two decades or so, is to read Geoffrey's work in light of Anglo-Norman expansion, and Michael Faletra's chapter does just that, arguing that Geoffrey's work supports colonialist policies. Politics also provides the backdrop for Fiona Tolhurst's chapter, which argues that, because of its pro-Angevin and thus pro-Empress stance, Geoffrey's work displays feminist leanings. Next, Coral Lumbley discusses Geoffrey in light of a growing interest among medievalists in the construction of race, and she demonstrates that Geoffrey's history should be read as one of the controlling texts of medieval racial discourse, especially in the British Isles. Finally, Barry Lewis overturns the long-standing critical commonplace that Geoffrey was simply not that interested in religious matters. These chapters all reveal the versatility of Geoffrey's work, and show that it has much to offer scholars in a variety of fields and with a variety of critical approaches. Of course, these four chapters should not be taken as a definitive list of all that is possible. An eco-critical approach to Geoffrey's work might well prove useful, especially with Geoffrey's intense interest in place. And this volume feels 
the lack of art historians, many of whom, given Geoffrey's broad reception, could surely produce a chapter on visual representations of his work. For these omissions and others, the editors are heartily sorry, and we offer the same invitation that Geoffrey of Monmouth offered to his contemporary Caradog of Llancarfan: we leave these matters to others to write.

Yet even 14 chapters cannot cover the necessary ground to make any claims to comprehensiveness. Accordingly, this volume limits its focus to Geoffrey's immediate work and life, though our contributors have been permitted occasional forays into other terrain. Nevertheless, Geoffrey's reception posed a challenge for this volume. Given the widespread popularity of the $D G B$, anything that fully treated its reception would transform an already bulky book into several bulky books. Rather than ignore Geoffrey's posthumous appeal altogether, we have thought it better to include as a final part a series of shorter, encyclopedia-like entries on the reception of his work in various linguistic traditions. Only the Welsh, French, and Latin receptions have been accorded their own full chapters, given the importance of these three traditions to Geoffrey. (Nevertheless, we have also thought it best to include Welsh and French reception articles for the sake of thoroughness, especially since these smaller versions offer a more concise bibliographic overview). These shorter articles in the final part are meant to offer points of entry into his reception in as many traditions as we could identify, and they also make for interesting reading regarding the how and why of his popularity (or lack thereof) in different cultural contexts. We encourage readers who have identified other linguistic and cultural traditions into which his work was received to take this volume as a jumping-off point and to continue broadening the critical conversation about the reception of his texts.

One part of Geoffrey's reception that this volume does not cover explicitly though our authors touch upon it here and there - is the two variant Latin versions of the $D G B$. The First Variant Version has received excellent attention from Neil Wright, and we would direct curious readers to his work. ${ }^{8}$ The Second Variant Version has no critical edition, and so for the moment it is difficult to say anything of worth about it. ${ }^{9}$ Since companion volumes cover what is normally found in introductory material - sources, methods, and the like - the rest of this introduction concerns Geoffrey's biography, if indeed we can call a life with only a few concrete facts a "biography" at all.

8 First Variant Version, ed. Wright. Unfortunately, the following work, which provides a revisionist account of the First Variant Version, only became available in the late stages of this book: The History of the Kings of Britain: The First Variant Version, ed. and trans. D.W. Burchmore, Cambridge, MA, 2019.

9 See $D G B$, pp. x-xi; Crick, $D R$, pp. $15^{-16}$. 
For the man who invented King Lear and Arthurian literature as we know it, the details of Geoffrey's life remain largely a mystery. ${ }^{10}$ Compared to some of his contemporaries, Geoffrey is not particularly forthcoming about biographical details, and he leaves modern scholars little to work with. Still, he had the courtesy (or perhaps audacity) to sign his works, something that many medieval writers did not feel compelled to do, and this information provides the basis for our knowledge of Geoffrey's life. He calls himself Galfridus Monemutensis on three occasions: once in the $P M$ and twice in the $D G B .{ }^{11}$ And in the $V M$ he styles himself de Monemuta. ${ }^{2}$ Some connection with Monmouth is therefore assured, probably implying that he was born in Monmouth and spent his early life there. The local knowledge displayed in his works shows that he was familiar with the region around Monmouth, and so it is probably safe to assume that he was born in or near Monmouth around 110o.13 The date for Geoffrey's birth "circa 110o", widely repeated in scholarship, works backwards from his appearance at Oxford in 1129, after he had obtained an early education and the title magister. However, it is important to remember that nothing is certain in this regard, and Geoffrey could have been born as early as 1070 and died in his eighties. His deep erudition and mastery of Latin points to an early education, and in the first few decades of the 12th century, Monmouth Priory would have been a possible place for a local boy to receive instruction in grammar. Geoffrey may even be the same Gaufridus scriba, "Geoffrey the scribe", who witnessed a 1120 charter concerning the priory's property. ${ }^{14}$ The early connection with Monmouth priory, however, remains speculative.

Over the last century a broad scholarly consensus has emerged that Geoffrey spent a good deal of his life in Oxford, and that he was a canon of St George's,

10 For Geoffrey's life see:J.E. Lloyd, A History of Wales from the Earliest Times to the Edwardian Conquest, 2nd ed., London, 1912, pp. 523-25; H.E. Salter, "Geoffrey of Monmouth and Oxford", EHR 34 (1919), 382-85; E. Faral, "Geoffrey of Monmouth: les faites et les dates de sa biographia", Romania 53 (1927), 1-42; L. Thorpe, "The last years of Geoffrey of Monmouth", in n.n. (ed.), Mélanges de langue et littérature françaises du moyen âge offerts à Pierre Jonin, Aix-en-Provence, 1979, pp. 663-72; M.D. Legge, "Master Geoffrey Arthur", in K. Varty (ed.), An Arthurian Tapestry: Essays in Memory of Lewis Thorpe, Glasgow, 1981, pp. 22-27; O. Padel, "Geoffrey of Monmouth and Cornwall", cMcs 8 (1984), 1-28, esp. at pp. 1-5; Karen Jankulak, Geoffrey of Monmouth, Cardiff, 2010, pp. 5-12; J.C. Crick, "Monmouth, Geoffrey of (d. 1154/5)", Oxford Dictionary of National Biography, Oxford University Press, 2004, <http://www.oxforddnb.com/view/article/10530> (accessed 27 June 2018).

$11 \quad D G B$, vii.110.21; Prologus 3.19; xi.177.1.

$12 V M, 1.1526$.

13 Tatlock, $L H B$, pp. $72-77$.

14 Chartes anciennes du Prieuré de Monmouth en Angleterre, ed. P. Marchegay, Les Roches-Baritaud, 1879, pp. 21-22, no. 8. See also J.E. Lloyd, "Geoffrey of Monmouth", EHR 57 (1942), 46o-68, at p. 461, n. 2; Tatlock, $L H B$, p. 440. 
a short-lived collegiate church inside Oxford Castle, founded in 1074 by Robert d'Oyly and Roger de'Ivry. ${ }^{15}$ The central plank of this argument is eight Oxford charters, dating from 1129 to $1151^{16}$ In these charters, a "Galfridus Arturus" (with slight orthographical variations) appears as a witness. The subjects of these charters and their witnesses make it very likely that the Galfridus Arturus appearing therein was a canon of St George's. ${ }^{17}$ This "Geoffrey Arthur" of the Oxford charters has been identified with Geoffrey of Monmouth for the following reasons. First of all, four 12th-century writers call Geoffrey of Monmouth "Geoffrey Arthur", with William of Newburgh helpfully revealing that Geoffrey was nicknamed "Arthur" (agnomen habens Arturi). ${ }^{18}$ These

15 In some scholarship, there is marked confusion as to whether Geoffrey was a secular canon or an Augustinian (thus regular) canon. Augustinian canons lived under a rule, and thus were in some ways akin to monks, while secular canons did not live under a rule. The confusion seems to have arisen in the following manner: there is no evidence that the collegiate church of St George in Oxford Castle was Augustinian. However, the nearby Augustinian house of Oseney acquired St George's as early as 1149. It is difficult to know if Oseney made the previous canons of St George's follow their rule, but they did allow them to possess their prebends for the rest of their lives, which suggests some respect for the status quo and a "friendly" takeover. And even after Oseney assumed its control, St George's remained a parish and employed secular canons. At any rate, it is hardly fair to call Geoffrey an Augustinian if he only became (perhaps unwillingly) affiliated with that order in the last few years of his life. Indeed, if he had chosen an Augustinian house, especially early in his life, it might be an important piece of evidence regarding his religious outlook. It is therefore difficult to see any Augustinian influence in his two earlier works (pace Tatlock, $L H B$, p. 82; for a better explanation of some Augustinian connections, see p. 163 of this volume) since he finished them well before St George's was absorbed into Oseney. Tatlock's clumsy phrase, "[t]he Augustinian secular canons' college of St. George" (p. 441), echoed in Thorpe's widely consulted translation "Augustinian canons of the secular college of St. George" (Geoffrey of Monmouth, De gestis Britonum, trans. L. Thorpe, Geoffrey of Monmouth: The History of the Kings of Britain, London, 1966, p. 12) has given the impression that Geoffrey was an Augustinian. However, if Geoffrey is to be thought of as a canon of St George's - and I am in agreement that the evidence strongly suggests so - he is best thought of as a secular canon. For the collegiate church of St George, see J. Barron, "The Augustinian Canons and the University of Oxford: the Lost College of St George", in C.M. Barron and J. Stratford (eds.), The Church and Learning in Later Medieval Society: Essays in Honour of R.B. Dobson, Donington, 2002, pp. 228-54; W. Page (ed.), The Victoria History of the County of Oxford: Volume II, London, 1907, pp. 160-61; C. Brooke, R. Highfield, \& W. Swaan, Oxford and Cambridge, Cambridge, 1988, pp. 49-50.

16 Salter, "Geoffrey of Monmouth and Oxford". The eighth is found in Facsimiles of Early Charters in Oxford Muniment Rooms, ed. H.E. Salter, Oxford, 1929, no. 102. Two of these charters Salter identifies as forgeries (no. 2 and no. 102). For a note on Salter's transcription, see $D G B$, p. vii, n. 1 .

17 Salter, "Geoffrey of Monmouth and Oxford", p. 385.

18 William of Newburgh, The History of English Affairs, ed. and trans. P.G. Walsh and M.J. Kennedy, William of Newburgh: The History of English Affairs, Book I (Edited with 
references, independent of the charters, are the strongest evidence that the two Geoffreys are the same, but that is not all. Two early families of $D G B$ manuscripts append the cognomen "Arthur" to Geoffrey in the title. ${ }^{19}$ Moreover, the co-witnesses who appear alongside Geoffrey Arthur in the Oxford charters are also telling: Walter, the archdeacon of Oxford, who is said to have provided the source for the $D G B$, and Ralph of Monmouth, a canon of Lincoln. Ralph was not the only one at St George's with a connection to Lincoln, since Robert de Chesney, who would later become bishop of Lincoln (1148-66), was also a canon there. While Oxford lay within the sprawling medieval diocese of Lincoln, and thus some affiliation is unremarkable, these Lincoln connections are nonetheless noteworthy in Geoffrey's case because he dedicated the $P M$ and the $V M$ to two successive bishops of Lincoln, Alexander (1123-48) and Robert de Chesney. Yet another reason to link the Geoffrey from the Oxford charters and Geoffrey of Monmouth is that in the Oxford charters "Arthur" is unlikely to be a patronym. ${ }^{20}$ In the charter collocations, the name "Artur" never once appears in the genitive case, as would be expected if it were a patronym. Instead, in the charters "Arthur" appears to be an agnomen, a nickname, and as such indicates that the Oxford Geoffrey had a particular interest, one might even say obsession, with the figure of Arthur. ${ }^{21}$ How many budding Arthurian scholars named Geoffrey could there have been in the mid-12th century? Another name also suggests that the two Geoffreys are one and the same - Boso of Oxford, who

Translation and Commentary), Warminster, 1988, pp. 28-29. On this passage, see Padel, "Geoffrey of Monmouth and Cornwall", p. 3 and Meecham-Jones's contribution to this volume. For Henry of Huntingdon, see History of the English, Letter to Warin. Gerald of Wales, The Journey Through Wales i.5, ed. J.F. Dimock, Giraldi Cambrensis Opera, 8 vols., London, 1861-91, vol. 6, pp. 3-152, at p. 58; The Description of Wales, i.7, ed. J.F. Dimock, Giraldi Cambrensis Opera, 8 vols., London, 1861-91, vol. 6, pp. 153-228, at p. 179. For William of St Albans, see William of St Albans, Life of St Alban, trans. T. O'Donnell and M. Lamont, in J. Wogan-Browne and T.S. Fenster (eds.), The Life of St. Alban by Matthew Paris, Tempe, 2010, pp. 133-65, at p. 139; the Latin text is found in Acta sanctorum (June IV, 22). See also Tatlock, $L H B$, p. 439. To Tatlock's count (I have excluded his citation of Matthew Paris because, as he notes, it is late and dependent on earlier sources) can be added The Waverley Chronicle, ed. H.R. Luard, Annales Monastici, 5 vols., London, 1864-69, vol. 2, pp. 129-411, at pp. 234-35.

19 See the variants on the title for $Q$ and $M$ in $D G B$, p. 3. Indeed, according to Reeve, $M$ (London, British Library, Royal 13 D. ii) has a particularly good textual pedigree: "a transcript of M would be a tolerable substitute for an edition" ( $D G B$, p. xvi).

20 See, for example, Padel, "Geoffrey of Monmouth and Cornwall", pp. 1-3. Pace, M.J. Curley, Geoffrey of Monmouth (Twayne's English Authors Series, 509), New York, 1994, p. 2 and Tatlock, $L H B$, p. 439. See below for more discussion.

21 Padel in "Geoffrey of Monmouth and Cornwall" helpfully suggests the discrepancy in names arose because "Geoffrey himself preferred Monemutensis, while others used Artur of him; or that in his literary works he preferred to use an epithet which did not show him to have particularly Arthurian connections" (p. 4). 
appears as a minor character in the $D G B .{ }^{22}$ J.S.P. Tatlock believed the name Boso was a pun on the Latin name for Oxford, Vadum Boum. ${ }^{23}$ (The apparent pun is more easily grasped in the nominative singular, bos, "ox, bull"). However, the name Boso would have also had an immediate connotation for Geoffrey's educated contemporaries. In the previous generation, Anselm of Canterbury had explored incarnational theology in his influential Why God Became a Man. The form of this work is a dialogue between Anselm and his pupil Boso, who by argumentative necessity is rather dull and dimwitted. The peculiar name Boso therefore would have called to mind a dullard scholar who needed matters explained to him in the simplest of terms. It is not farfetched to read the Boso of Oxford in the $D G B$ as a joke directed at Geoffrey's colleagues at Oxford, and thus we would have another connection between Geoffrey of Monmouth and Oxford. Assured that we are dealing with one Geoffrey, we can mine the Oxford charters for two additional pieces of biographical evidence: they tell us that Geoffrey was a magister and that he was elected bishop of St Asaph. ${ }^{24}$

The exact connotations of the title magister vary in place and time, but in England during Geoffrey's day the title generally means that one had obtained a higher education. ${ }^{25}$ As far as we know, this makes Geoffrey one of only four men with the title magister who were teaching at Oxford schools around the same time. ${ }^{26}$ Where Geoffrey obtained that education is another matter altogether. It is sometimes suggested that Geoffrey went to Paris for advanced study, but this is little more than projecting the attraction that Parisian schools held for later British generations back onto Geoffrey. And while it is plausible that he might have been educated at Paris or another burgeoning proto-university, it is just as plausible that Geoffrey could have received his title "magister" from a training in a monastic, collegiate, or cathedral school. ${ }^{27}$ Judging by the other three magistri at Oxford, all of whom were theologians, it seems that the title might imply he lectured on theology. ${ }^{28}$ His skill with the written word, however, shows that he would not have been out of place lecturing on grammar or rhetoric, or perhaps even dialectic. Still, we do not need the

$22 \quad D G B$, i.156.338-39: "Boso Ridochensis, id est Oxenefordiae". Boso again appears during Arthur's campaign against Rome.

23 Tatlock, $L H B$, p. 169 .

24 Salter, "Geoffrey of Monmouth and Oxford", pp. 384-85.

25 J. Barrow, The Clergy in the Medieval World: Secular Clerics, Their Families and Careers in North-Western Europe c.80o-c.120o, Cambridge, 2015, pp. 208-10, esp. n. 2. See also Legge, "Master Geoffrey Arthur" and Barron, "Augustinian Canons", pp. 235-36.

26 Legge, "Master Geoffrey Arthur", p. 24.

$27 D M L B S$, s.v. magister, def. 5 a and 11. My thanks to an anonymous reader for this suggestion.

28 Legge, "Master Geoffrey Arthur", p. 24. 
Oxford charters to tell us that Geoffrey was an educated man - his work leaves no doubt - but they do provide one more detail about his biography, and a fascinating one at that. The last two Oxford charters show that in 1151 he had been elected bishop of St Asaph, a newly created diocese in northeastern Wales, itself built on the bones of an older Welsh diocese and apparently designed to counterbalance the preeminence of the diocese of Bangor to its west. ${ }^{29} \mathrm{He}$ would have been only the third bishop of this new bishopric, and it is difficult to resist speculation of what it might have meant that Geoffrey, a Monmouth man who spent a tremendous amount of energy on the British past, was elected to a Welsh see with strong English leanings. ${ }^{30}$ It was not uncommon for clergy who were not yet priests to postpone their ordination into the priesthood until their careers required it, and so on 16 February $115^{2}$ he was ordained a priest at Westminster Cathedral, and only eight days later at Lambeth Palace he was consecrated bishop. ${ }^{31}$ It is as a bishop that we catch the last documentary evidence of his life as a witness to the Treaty of Westminster in $1153 \cdot{ }^{32}$ It has been suggested that the provincial nature of St Asaph "was scarcely suited to a man of Geoffrey's urbane and scholarly character", but a bishopric was a bishopric, and it is unlikely that Geoffrey or his colleagues would have scoffed at the promotion..$^{33}$ We probably underestimate his ecclesiastical career at our own peril, if we view his work, as Tatlock did, as indicative of his "secularity of interests". ${ }^{34}$ Instead, as Barry Lewis's chapter in this volume shows, Geoffrey

29 S. Harris, "Liturgical Commemorations of Welsh Saints II: St. Asaf", Journal of the Historical Society of the Church in Wales 6 (1956), 5-24, at pp. 5-7; J.E. Lloyd, "Geoffrey of Monmouth", pp. 465-66.

$30 \quad$ For the early bishops, see "St Asaph: Bishops", ed. M.J. Pearson, Fasti Ecclesiae Anglicanae 1066-1зо0: Volume 9, the Welsh Cathedrals (Bangor, Llandaff, St Asaph, St Davids), London, 2003, pp. 33-36, British History Online, <http://www.british-history.ac.uk/fasti -ecclesiae/1066-13oo/vol9/pp33-36> (accessed 6 May 2019).

Gervase of Canterbury, Chronicle, ed. W. Stubbs, The Historical Works of Gervase of Canterbury, 2 vols., London, 1879-80, vol. 1, p. 142 and n. 2; The Canterbury Professions, ed. M. Richter, Torquay, 1973, p. 47, no. 95. Now for some chronological housekeeping: In both his profession and Gervase, the year is reported incorrectly. Stubbs explains this error, noting that the only proximate year in which "septimo kalendas Martii" fell on a Sunday was 1152, a leap year. Confusingly, The Canterbury Professions is silent on this matter, listing only 1151, an error which is pointed out in Fasti Ecclesiae Anglicanae. Even more confusingly, the Fasti Ecclesiae Anglicanae itself makes an error while pointing out the error in The Canterbury Professions: it lists the day of his consecration and profession of obedience as 23 March, instead of 24 February.

34 Tatlock, $L H B$, p. 446. 
was very much interested in sacred matters. When the Brut y Tywysogyon records his death in 1155, no mention is made of his $D G B$, which would become wildly popular in Wales. ${ }^{35}$ Rather, it is his designation as bishop which carries his weight for posterity.

One hotly debated question in Galfridian scholarship, indeed perhaps the most hotly debated, also concerns Geoffrey's biography. What was his ethnicity or, to use a medieval term, his gens? Intimately bound up in this question is discussion of Geoffrey's attitude toward Wales. Was Geoffrey Welsh, Breton, or Anglo-Norman, or perhaps even a Cornish sympathizer? ${ }^{36}$ And did he intend his literary works to support the Welsh cause, to justify Anglo-Norman conquest of Wales, or to play to both sides, allowing supporters of whatever faction to find succor in his spirited account of the British past? There exists, of course, more nuance than this bare summary of over a century of scholarship can suggest, but most scholarship on Geoffrey falls into these categories, either explicitly or implicitly.

Investigations into Geoffrey's ethnicity circle around a few pieces of evidence. First is the name "Geoffrey", which does not seem to have been popular in Wales and had a distinctively continental flavor. ${ }^{37}$ Monmouth, moreover, had been under the lordship of Bretons since at least 1086, and a large number of Bretons had settled there. Brittany also looms large in the $D G B$, often appearing as the favored region and providing crucial military support. And

35 Brut y Tywysogyon; or, The Chronicle of the Princes. Red Book of Hergest Version, ed. and trans. T. Jones (History and Law Series, 16), Cardiff, 1955, 2nd ed., 1973, pp. 132-33: "Yn y ulwydyn honno y bu uarw Jeffrei, escob Lan Daf", "In that year Geoffrey, bishop of Llandaff, died." Lan Daf here is a mistake for Lan Elwy, the name of the diocese in Welsh. See J.E. Lloyd, A History of Wales, p. 525, n. 154.

36 For Geoffrey as Welsh, see J. Gillingham, "The Context and Purposes of Geoffrey of Monmouth's History of the Kings of Britain", Anglo-Norman Studies 13 (1990), 99-118 (repr. in id. (ed.), The English in the Twelfth Century: Imperialism, National Identity and Political Values, Woodbridge, 200o, pp. 19-39). For Geoffrey as a Breton, see J.E. Lloyd, A History of Wales, pp. 523-24; id., "Geoffrey of Monmouth", pp. 466-68; Tatlock, LHB, pp. 397-40O, 443-44. For Geoffrey as a supporter of Anglo-Norman interests, see M.A. Faletra, "Narrating the Matter of Britain: Geoffrey of Monmouth and the Norman Colonialization of Wales", The Chaucer Review 35:1 (2000), 60-85; id., Wales and the Medieval Colonial Imagination: The Matters of Britain in the Twelfth Century, New York, 2014; M.R. Warren, History on the Edge: Excalibur and the Borders of Britain, 1100-1300 (Medieval Cultures, 22), Minneapolis, 2000; P. Dalton, "The Topical Concerns of Geoffrey of Monmouth's Historia Regum Britannie: History, Prophecy, Peacemaking, and English Identity in the Twelfth Century", Journal of British Studies 44:4 (2005), 688-712. For Geoffrey's Cornish sympathies, see Padel, "Geoffrey of Monmouth and Cornwall". For doubt all around, see Jankulak, Geoffrey of Monmouth, pp. 11-12.

J.E. Lloyd, A History of Wales, p. 523; id., "Geoffrey of Monmouth", pp. 466-67. 
Geoffrey's intention to write another British history, this time about the flight of the native church into Brittany, has been viewed as another indication of Breton partiality. ${ }^{38}$ Finally, his appointment as bishop of St Asaph suggests that he was a candidate of the Anglo-Norman establishment; they would not have chosen a Welshman or a Welsh partisan as a bishop for a newly formed Welsh diocese that was intended to push back against the diocese of Bangor. ${ }^{39}$ Taken together, this evidence suggests that Geoffrey felt himself to be Breton, born into a Breton family at Monmouth (or perhaps even in Brittany itself and later brought to Monmouth). The Breton solution has found significant support because it elegantly answers an apparent contradiction: how could a man born in Monmouth (and thus Welsh) narrate his people's fall into disrepute and Insular irrelevance, all while favoring Brittany of all places? The description of Wales at the end of the $D G B$ certainly arouses no native pride, and viewing Geoffrey as a Breton, fascinated by but not beholden to the land of his birth, offers a way around this problem. Understandably, many have followed Tatlock's lead in proclaiming Geoffrey to be a "Breton patriot". 40

However, the Breton solution is not without its difficulties. The idea first appeared in J.E. Lloyd's A History of Wales from the Earliest Times to the Edwardian Conquest (1911), in which Lloyd outlined the three major strands of the argument: Geoffrey's name, the Breton settlement at Monmouth, and the work's apparent partiality to Brittany. ${ }^{41}$ Before reassessing the evidence, it is helpful to understand the genealogy of this argument by examining Lloyd's own treatment of Geoffrey. Overall, Lloyd's patriotic vision of who counted as Welsh and what counted as Welsh history was heavily informed by his Victorian and Edwardian education and not as capacious as our modern standards might have it. ${ }^{42}$ Accordingly, in Lloyd's account Geoffrey was "a foreigner", and whereas we might be prone to viewing Geoffrey as a creative and masterful writer, Lloyd demeaned him as "a mere romancer" - a damning term from an exacting historian. ${ }^{43}$ (Lloyd did, however, credit Geoffrey for "giving world-wide currency" to "the ancient traditions of Wales".) ${ }^{44}$ It is easy to speculate that

$38 \quad D G B, x i .186 .169$.

39 J.E. Lloyd, "Geoffrey of Monmouth", p. 465; Tatlock, $L H B$, p. 443.

40 Tatlock, $L H B$, p. 443.

41 J.E. Lloyd, A History of Wales, pp. 523-24. Lloyd revisited the idea in "Geoffrey of Monmouth", pp. 467-68.

42 H. Pryce,J.E. Lloyd and the Creation of Welsh History:Renewing a Nation's Past, Aberystwyth, 2011, esp. pp. 169-76 for a summary of Lloyd's nationalist project; id., "J.E. Lloyd's History of Wales (1911)", in N. Evans and H. Pryce (eds.), Writing a Small Nation's Past: Wales in Comparative Perspective, 1850-1950, Farnham, 2013, pp. 49-64.

43 J.E. Lloyd, A History of Wales, p. 524; p. 182, n. 82. See also, Pryce, J.E. Lloyd, p. 99.

44 J.E. Lloyd, $A$ History of Wales, p. 523. 
Lloyd, whose own work revolutionized and professionalized the study of medieval Welsh history, saw in Geoffrey much of the same inventive spirit that had gummed up the study of Welsh history in the 18th and 19th centuries. ${ }^{45}$ But Lloyd's insistence that Geoffrey was not Welsh does not seem to stem from an inability to recognize that earlier Welsh historians could get things wrong, sometimes disastrously so. Indeed, the fact that Lloyd felt compelled to address Geoffrey's ethnicity, and then returned to the same question some 30 years later, hints at something more, especially since for an earlier generation of critics the major crux of Geoffrey's work was not where its national sympathies lay, but whether Geoffrey's history was a translation or an original work. ${ }^{46}$ Lloyd's discomfort with Geoffrey's status as Welsh seems to arise from an inability to accept that one of his own countrymen could end a history of Wales on such an inglorious note. The Breton hypothesis solves a problem that existed for Lloyd, but that did not exist for Geoffrey, at least in the same terms: "the problem of how a foreigner came to be so deeply interested in the legends of the old British time". ${ }^{47}$ This phrasing, moreover, neatly avoids the alternative, which was perhaps even more troubling to Lloyd: the problem of how a Welshman came to chronicle, in a specious history, his nation's fall into disrepute. Lloyd's own patriotic reading of Welsh history ended with determined promise, decidedly at odds with Geoffrey's, and I would tentatively suggest Geoffrey's lack of apparent patriotism suggested to Lloyd a decidedly "nonnative" feel. ${ }^{48}$ At any rate, it is ironic that Lloyd's work, which was written, read, and received as a national panegyric, essentially deprived Wales of its most influential author. Nonetheless, despite the genesis of the Breton argument out of this nationalist framework, Lloyd's scholarly stature meant that others soon followed suit. Edmund Faral's influential study of Geoffrey begins, "In all likelihood, he was born in Monmouth in Gwent, and he was Breton by race".49

45 Pryce, J.E. Lloyd, pp. 95-113 and 116-18.

46 For example, it did not occur to the perceptive critic Thomas Stephens to question Geoffrey's own ethnicity, as his discussion is almost entirely devoted to proving that Geoffrey's history was largely an original work; see T. Stephens, The Literature of the Kymry: being a critical essay on the history of the language and literature of Wales during the twelfth and two succeeding centuries, Llandovery, 1849, pp. 307-23. Stephens, however, like other critics before Lloyd, follows Iolo Morganwg's short but fictional biography of Geoffrey (on which see below).

47 J.E. Lloyd, $A$ History of Wales, p. 524.

48 J.E. Lloyd, A History of Wales, p. 764: "It was for a far distant generation to see that the last Prince had not lived in vain, but by his life-work had helped to build solidly the enduring fabric of Welsh nationality."

49 Faral, $L L A$, vol. 2, p. 1: "Il était né, selon toute vraisemblance, á Monmouth, dans le Gwent, et il était de race bretonne", but see also vol. 2, p. 392. 
Tatlock followed this same line of thinking, adding a few other pieces of evidence: an English archbishop would not have appointed a Welsh bishop and Geoffrey seems to only display a superficial knowledge of the Welsh language. ${ }^{50}$ This list of evidence has remained static for the last 70 years, and though the Breton argument still has its adherents - some of whom are in this volume another look at the evidence leaves this editor unconvinced.

First, the name. Lloyd assumed that 12th-century references to "Geoffrey Arthur" meant that his father's name was Arthur, a popular Breton name at the time, but as discussed above the "Arthur" in Geoffrey's name is, to all appearances, a nickname that became attached to him because of his interest in Arthuriana. ${ }^{51}$ Nonetheless, it is true that the name Geoffrey was not popular in Wales before the Norman Conquest, but Lloyd goes too far when he claims "a Geoffrey of this time would scarcely be a Welshman." ${ }^{2}$ The study of prosopography has progressed a good deal since Lloyd's day, and it now seems clear that, lacking any other evidence, it is difficult to attach ethnicity to Geoffrey on the basis of his name alone. Choosing a continental name 14 or so years after a Breton became lord over Monmouth and some 34 or so years after the Norman Conquest might make Geoffrey's parents nothing more than early adopters of a name that would soon become popular in Britain. There were, after all, social benefits to a trendy name. Consider the case of an Englishman named Alfwy: Alfwy, who would have been around the same generation of Geoffrey of Monmouth, is said to have been "called Geoffrey as a mark of respect", presumably because the continental name carried more cultural caché than his given English name. ${ }^{53}$ Moreover, Alfwy and his wife Goda abandoned good English

5 O LHB, p. 443, p. 445 .

51 J.E. Lloyd, $A$ History of Wales, p. 524; “Geoffrey of Monmouth", p. 467, esp. n. 1. On the basis of chronology, Lloyd dismissed William of Newburgh's convincing explanation of Geoffrey's name, but see Padel, “Geoffrey of Monmouth and Cornwall”, pp. 1-4 for a demonstration that "there is no objection to the assumption that William knew what he was talking about" (p. 3). Moreover, Lloyd did recognize that the Latin forms of the name were not in his favor, but he never addresses this discrepancy; see "Geoffrey of Monmouth", p. 467 , n. 1. Tatlock in $L H B$, p. 439 recognized the same difficulty, but in response simply asked, "But who can assert how 'mab Arthur' would be Latinized?" It is true that a fuller study of how the English dealt with Welsh names remains a desideratum, but patronymic naming patterns were the norm in the Insular world, where names with fitz, son, and mac were encountered with regularity; $\mathrm{mab} / \mathrm{ap} / \mathrm{ab}$ would have presented little difficulty. Many English chroniclers Latinize Welsh patronymics with filius, suggesting that they were analyzable and therefore easily understood.

52 J.E. Lloyd, $A$ History of Wales, p. 523.

53 K.S.B. Keats-Rohan, "What's in a Name? Some Reflections on Naming and Identity in Prosopography”, in A.M. Jorge, H. Vilar, and M.J. Branco (eds.), Carreiras Eclesiásticas no 
names and named their two sons "Geoffrey" and "Robert".54 Alfwy, it would seem, knew the benefits of a fashionable name. To be clear, names sometimes are good indicators of ethnicity, but in post-Conquest England and southeastern Wales, where there would have been ample cultural pressure to adapt to the continental elite, especially among the lower nobility, a continental name on its own implies status, or sought-after status, not necessarily ethnicity. I have been writing "continental" instead of "Breton", because the name Geoffrey is itself Germanic and Norman in origin. Any popularity that it obtained among actual Bretons resulted from a similar process of appropriation, wherein Norman names became popular among non-Normans. Thus, even if "Geoffrey" were an infallible marker of ethnicity, it would be difficult to tell whether that ethnicity was Norman or Breton. Finally, there are other Geoffreys lurking in southeastern Wales in the early 12th century. At the Benedictine priory of St Mary in Monmouth, there were no fewer than eight Geoffreys. ${ }^{55}$ The brother of Urban, the bishop of Llandaff, apparently had two names, "Stephen" and "Geoffrey". 56 And in an 1146 charter, Bishop Uhtred of Llandaff, "a Welsh bishop of the old school, being married with a daughter called Angharad", had a nephew with the decidedly new-school name, Geoffrey. ${ }^{57}$ Are we to identify all of these men as Bretons? Instead, it is safer to say that the prestige of continental names was high in and around southeastern Wales in the late 11th and early 12th century.

As for the matter of the Welsh and bishoprics, Gerald of Wales was certainly under the impression that the Welsh were barred from episcopal office. ${ }^{58} \mathrm{But}$ Gerald complained about this slight a generation after Geoffrey had died, with a different political situation in place, and with no small amount of personal investment. Certainly, it is not wise to deny that anti-Welsh bias operated in the 12th century, but it is equally wise not to take Gerald's personal grievances at his word. At any rate, as Gerald well knew, his own uncle David fitz Gerald had been elected bishop of St Davids in 1148, just a few years before Geoffrey

Ocidente Cristão (séc. XII-XIV). Ecclesiastical Careers in Western Christianity (12th-14th c.), Lisbon, 2007, pp. 331-47, at pp. 335-36.

54 Keats-Rohan, "What's in a Name?" p. 336.

55 See $V M$, pp. 27-28. Clarke calls the popularity of the name Geoffrey "local fashion" (p. 27). He has extracted the names from the charters edited in Chartes anciennes, ed. Marchegay.

56 See J.R. Davies, The Book of Llandaf and the Norman Church in Wales, Woodbridge, 2003, at pp. 119, 129 .

57 J.R. Davies, The Book of Llandaf, p. 55. Furthermore, in another example of the popularity of continental names, Uhtred's own son was called "Robert"; "Uhtred" is itself an early English name. For the witness, see Llandaff Episcopal Acta, 1140-1287, ed. D. Crouch, Cardiff, 1989, no. 2.

58 Gerald of Wales, The Rights and Status of the Church of St Davids i, ed. J.S. Brewer, Giraldi Cambrensis Opera, 8 vols., London, 1861-91, vol. 3, pp. 99-373, at pp. 120-23. 
became bishop of St Asaph. With a Welsh mother and a Norman father, David could appease both sides, and his case certainly shows that Gerald's complaints do not hold true for the middle of the century (especially since David the uncle could claim to have more Welsh blood than Gerald the nephew, who only had one Welsh grandparent). In the very same year that David was elected, Nicholas ap Gwrgan became bishop of Llandaff, the other southern Welsh diocese. And although Nicholas had been a monk at the abbey of St Peter's, Gloucester for most of his life - it was not unheard of for Welshmen from southeastern Wales to seek out that abbey - he apparently had a Welsh father and acted as a gobetween for the Glamorgan Welsh and the earl of Gloucester. ${ }^{59}$ Just a few years after Archbishop Theobald had consecrated David and Nicholas, he made Geoffrey bishop of St Asaph. Finally, the archbishop had previously appointed another Welshman, Meurig, as the bishop of Bangor in 1140. Meurig had trouble with both the secular and ecclesiastical leaders of Gwynedd, falling out with his countrymen and fleeing to Canterbury ${ }^{60}$ Far from the impossibility of a Welshman becoming bishop, it seems that Theobald had a policy of appointing Welshmen who showed strong Anglo-Norman leanings: David had a Norman father; Meurig was reform-minded, irked Gwynedd nobility, and even swore fealty to King Stephen; Nicholas had been a monk at Gloucester and had the support of his influential former abbot, Gilbert Foliot; and Geoffrey had resided at Oxford for most of his life and his bona fides as a supporter of the Angevin cause were apparently not in question. Meurig's and David's appointments had setbacks, and their cases suggest that Geoffrey would have had to recognize the supremacy of Canterbury, which, based on how he dismissed St Davids' metropolitan aspirations in his own work, one imagines was freely given in exchange for a bishopric. In sum, I suspect, were he alive today, Archbishop Theobald's face would register astonishment if he were to read that Geoffrey would not have been granted a Welsh see "had he been a Welshman, even a well-affected Welshman", since he had indeed given three well-affected Welshmen sees on earlier occasions. ${ }^{61}$

59 D. Walker, "Nicholas ap Gwrgan (d. 1183), bishop of Llandaff", Oxford Dictionary of National Biography, Oxford University Press, 2014, <http://www.oxforddnb.com/view/ article/20086> (accessed $26 \mathrm{June} 2018$ ). It has sometimes been assumed that Nicholas was the son of the previous bishop of Llandaff, Urban, whose name appears as "Gwrgant" in Welsh. Urban's own ethnicity is uncertain.

6o The Acts of Welsh Rulers, 1120-1283, ed. H. Pryce, Cardiff, 2005, p. 323; id., "Esgobaeth Bangor yn Oes y Tywysogion" [The diocese of Bangor in the age of the princes], in W.P. Griffith (ed.), "Ysbryd Dealltwrus ac Enaid Anfarwol": Ysgrifau ar Hanes Crefydd yng Ngwynedd Ngwynedd ["Enlightened spirit and eternal soul": essays on the history of religion in Gwynedd], Bangor, 1999, pp. 37-57, at pp. 44-45.

61 Tatlock, $L H B$, p. 443. 
Furthermore, the dour ending of Geoffrey's history, at least for Welsh readers, need not imply that he was not Welsh. Geoffrey had a resourceful imagination, but historical exigency forced his hand, and even the most inventive author had to face the fact that the Welsh had lost the majority of Britain and that internecine feuding was rampant in Welsh politics. But more to the point, the assumption that Geoffrey must not be Welsh because he criticizes Welsh leaders and paints a dire picture of their current situation seems to me misguided. For Gildas, Wulfstan, or even commentators on current American politics, criticism of political leaders and the state of the nation does not necessarily imply that one does not belong to that polity. Indeed, the opposite seems more likely. The distance of goo years tends to flatten out complicated and shifting political beliefs, but it is not too difficult to imagine that Geoffrey could both be Welsh and criticize the Wales of his day. He was not even the only Welsh historian of his generation to give an ambiguous view of his countrymen, as the author of the "Llanbadarn History", who wrote sometime before 1127 , has much in common with Geoffrey's approach. ${ }^{62}$ Similarly, the author of Breudwyt Ronabwy ("The Dream of Rhonabwy") has Arthur praise the ancient Welsh while disparaging the Welsh who defend Britain in later times: "[...] I feel so sad that scum such as these are protecting this Island after such fine men that protected it in the past." ${ }^{\prime 3}$ Moreover, discussions of the ending of the $D G B$ have in general failed to take account of the intellectual climate of the 12th century. Although this period has at times been termed "the Renaissance of the 12th century", it was nonetheless a deeply pessimistic era. ${ }^{64}$ Writers decried the fallen state of humanity, and found the idealized past superior to the present, where scholarship, governance, and even love had degraded into a lamentable disarray. The ending of the $D G B$ falls completely in line with the dramatic pessimism that marks so many contemporary works. ${ }^{65}$

Still, it is undeniable that Geoffrey does place seemingly undue importance on Brittany in his history, which indeed suggests a Breton partiality of some sort. However, a familial connection to Brittany is not the only explanation.

62 O.W. Jones, "Brut y Tywysogion: the History of the Princes and Twelfth-Century Cambro-Latin Historical Writing", Haskins Society Journal 26 (2014), 209-27, at pp. 222-27.

63 Breudwyt Ronabwy: allan o'r Llyfr Coch o Hergest [The Dream of Rhonabwy, from the Red Book of Hergest], ed. M. Richards, Cardiff, 1948, pp. 6-7: “[...] truanet gennyf vot dynyon ky vawhet a hynny yn gwarchadw yr ynys honn gwedy gwyr kystal ac a'e gwarchetwis gynt"; The Mabinogion, trans. S. Davies, Oxford, 2007, pp. 214-26, at p. 217.

64 C.S. Jaeger, "Pessimism in the Twelfth-Century 'Renaissance', Speculum 78:4 (2003), $1151-83$.

65 A similar sentiment of despair is found in the $V M, 11.5^{80}-85$. 
Another possible explanation of this apparent bias relies on the pioneering work of Katharine Keats-Rohan. ${ }^{66}$ She has argued that the civil war of King Stephen's reign was, in large part, a war between two feuding Breton kinship groups with long-standing grievances. Her work has demonstrated that, with a few exceptions, the allegiances of the Bretons in the English civil war are entirely dependent on pre-existing kin-groups and their biases. The ins and outs of these two Breton groups are a complicated affair, but what is important for our purposes is that the Empress Matilda had the backing of a group of Bretons whose ancestral allegiances were to eastern Brittany: Dol, Cambour, and Fougères. Stephen, on the other hand, had the support of a group of Bretons led by Alan of Penthièvre, the count of Richmond. Geoffrey, for his part, has been described as a supporter of the Angevin cause during the civil war. ${ }^{67} \mathrm{He}$ dedicated the $D G B$ to Robert, earl of Gloucester, one of the Empress's doughtiest supporters, and the work's portrayal of female rulership would seem to support Empress Matilda's right to rule. ${ }^{68}$ Therefore, perhaps his valorization of Brittany owes more to Geoffrey's politics than to any personal connection? Such a view might help explain the favoritism he shows toward Dol, which was the heartland of those Bretons supporting the Empress, and the relative neglect of the rest of Brittany. ${ }^{69}$ It might also explain (in part) his devotion to

66 K.S.B. Keats-Rohan, "The Bretons and Normans of England 1066-1154: the Family, the Fief and the Feudal Monarchy", Nottingham Medieval Studies 36 (1992), 42-78; ead., "William I and the Breton Contingent in the Non-Norman Conquest 1060-1087", Anglo-Norman Studies 13 (1991), 157-72.

67 Crick, "Monmouth, Geoffrey of (d. 1154/5)"; ead., "Geoffrey of Monmouth, Prophecy, and History”, Journal of Medieval History 18:4 (1992), 357-71.

68 F. Tolhurst, Geoffrey of Monmouth and the Translation of Female Kingship, New York, 2013.

69 Although the Angevin cause did not pick up steam until 1139, after the Empress arrived in England and - importantly - after Geoffrey had written the $D G B$, Keats-Rohan shows that the allegiances of the Bretons in England were almost entirely predictable by their kinship groups and by grievances that went back well into the nth century. Thus, Geoffrey would have known that the Bretons in England who saw Dol and its environs as their ancestral homeland supported the Angevin cause. For the dating of the $D G B$ as a proMatilda text even though it was finished before the civil war proper began, see Tolhurst, Geoffrey of Monmouth, esp. pp. 54-73. Although Brynley Roberts follows Lloyd in claiming Breton descent for Geoffrey, he fleetingly suggests that Norman and Breton allegiances might have something to do with Geoffrey's praise of Brittany; see B.F. Roberts, "Sylwadau ar Sieffre o Fynwy a'r Historia Regum Britanniae" [Remarks on Geoffrey of Monmouth and the Historia Regum Britanniae], Llên Cymru 12 (1972-73), 127-45, at p. 129: "Mae'n wir fod amodau gwleidyddol y cyfnod yn ei gwneud yn anodd $\mathrm{i}$ awdur a geisiai nawdd llysoedd uchaf Lloegr glodfori'r Cymry, a'i bod yn naturiol iddo osod ei bwyslais ar y gangen honno o'r hen genedl a fu, rai ohonynt, yn gynghreiriaid â Normaniaid, ond er hynny, mae'n dra phosibl fod yma gydasiad ffodus o duedd bersonol a gofynion doethineb ymarferol", "It's true that the period's political conditions made it difficult for an author who wanted to 
Cornwall, since the leaders of Cornwall and Devon, of West Norman descent and allied to the Bretons of Dol, also supported the Empress. ${ }^{70}$ At any rate, space does not permit a full discussion of these matters, and I only wish to suggest that invoking Breton exceptionalism during the conflict between Stephen and Matilda had immediate political ramifications and does not necessarily point to Geoffrey's love of his own ancestral homeland.

Given all this, the idea that Geoffrey was of Breton descent because he favors Brittany and belittles Wales seems more and more like a just-so tautology designed to shoehorn Geoffrey's challenging work into a nationalist paradigm that did not exist in his own day. The central question that Lloyd sought to answer was how a Welshman could create a chronicle that praised the Bretons and offered seemingly little redemption to the Welsh, in stark contrast with Lloyd's own A History of Wales. An acceptable patriotic answer was to make Geoffrey a foreigner. This question, undergirded by a clunky nationalism that is ill-suited for a literary work like the $D G B$, still frames the debate on Geoffrey's ethnicity in a manner that constrains interpretations of his work. Instead, I would suggest that we approach Geoffrey's Breton favoritism with a different set of questions. First, what are the political ramifications of writing a history that gives Brittany a prominent role in British affairs during the reign of King Stephen? Does the pessimistic ending of the $D G B$ work in the same way as other instances of 12th-century nostalgia and pessimism, as a call to reform and a critique of current institutions? These, to my mind at least, are more promising questions.

Other scholars prefer to see Geoffrey as simply Welsh: he was from Monmouth, gave the Welsh a lavish history, and used Welsh sources. ${ }^{71}$ The only piece of roughly contemporary evidence that we have regarding Geoffrey's ethnicity - his origins in Monmouth aside - supports this view. A 12th-century copy of the $D G B$ in Oxford, Bodleian Library, Rawlinson C. $15^{2}$ contains the earliest version of a variant dedication of the $P M$ to Alexander, bishop of Lincoln. ${ }^{72}$ Here, Geoffrey's usual address to Alexander is replaced by his apology for the

gain the support of England's upper nobility to praise the Welsh, and it would be natural for him to emphasize that branch of the ancient race that had allied, at least in part, with the Normans, but in spite of that, it's exceedingly possible that here we are dealing with a fortunate union of personal bias and the demands of practical wisdom."

70 Keats-Rohan, "Bretons and Normans", p. 73. Further investigations along these lines might be profitably combined with the issues raised in Padel, "Geoffrey of Monmouth and Cornwall", pp. 17-20. See also E.M.R. Ditmas, "Geoffrey of Monmouth and the Breton families in Cornwall", WHR 6 (1972-73), 451-61.

71 For a representative overview, see Gillingham, "Context and Purposes".

72 See $D G B$, p. ix and Crick, $S C$, pp. $155^{-56}$, no. $15^{6}$. 
clumsiness of the prophecies in Latin, and it contains the following clause: "I, a bashful Briton, have not been taught how to sing what Merlin had sung sweetly and in verse in the British language."73 Although this variant dedication has a decidedly Galfridian ring to it and a good textual pedigree, it is difficult to know if it is to be attributed to a variant from Geoffrey himself, or from a slightly later adapter. Yet even if it is the latter, it would show that an early fan of Geoffrey's work believed, and thought others would believe, that he spoke the same language as Merlin, and that he was thus Welsh. It must be said however that Brito, "Briton", is a slippery word in the 12th century, and could mean any of the Brittonic peoples, all of whose languages were most likely still mutually intelligible. ${ }^{74}$ For that matter, attempts at uncovering Geoffrey's knowledge of Welsh have proven inconclusive, though it is clear that he had enough knowledge of the language to create Welsh etymologies and possibly access vernacular sources. ${ }^{75}$ (As an aside, one wonders whether the reluctance to credit Geoffrey with knowledge of Welsh, in spite of his familiarity with and interest in the language, reflects modern attitudes about which languages are accessible and which are not. All things being equal, knowledge of French or English seems more freely granted to medieval polyglots than Welsh or Irish). ${ }^{76}$ The same slipperiness appears at the end of the $V M$, where Geoffrey addresses Britanni, "Britons", and asks them to give a laurel wreath to him, since "[h]e is indeed your Geoffrey, for he once sang of your battles and those of your princes." ${ }^{77}$ Although it seems as if Geoffrey is claiming that he is a "Briton", the passage is anything but straightforward. ${ }^{78}$ However, Owain Wyn Jones, in his contribution to this volume, argues that Geoffrey was careful to distinguish

$73 D G B$, vii.11o, n. 12-24: "pudibundus Brito non doctus canere quod in Brittannico Merlinus dulciter et metrice cecinit." Translation mine.

74 For an overview of the nomenclature, see H. Pryce, "British or Welsh? National Identity in Twelfth-Century Wales", EHR 116 (2001), 775-801.

75 T.D. Crawford, "On the Linguistic Competence of Geoffrey of Monmouth", Medium Avum $5^{1}(1982), 15^{2-62 .}$

76 For instance, Tatlock, $L H B$, p. 445 generously grants Geoffrey knowledge of English based on little evidence, but remains skeptical of Geoffrey's knowledge of Welsh, refusing to state one way or another if he spoke Breton or Welsh, even though the $D G B$ shows far greater investment in these. Ben Guy reviews the evidence for Geoffrey's linguistic ability on pp. 39-42.

$77 V M$, ll. 1525-26: "Est enim vester, nam quondam prelia vestra / vestrorumque ducum cecinit."

78 See Guy's chapter in this volume. 
Brittany from Britain, and in light of that distinction it would seem that these passages suggest that Geoffrey was Welsh. ${ }^{79}$

Geoffrey's ethnicity is also tied up in another critical debate about the $D G B$. At the beginning of the $D G B$, finding himself contemplating the ancient history of Britain, Geoffrey announces the source for his own study:

I frequently thought the matter over in this way until Walter archdeacon of Oxford, a man skilled in the rhetorical arts and in foreign histories, brought me a very old book in the British tongue, which set out in excellent style a continuous narrative of all their deeds from the first king of the Britons, Brutus, down to Cadualadrus, son of Cadwallo. ${ }^{80}$

Earlier scholars sought to find Walter's book, or at least identify what texts this book might have contained, but most now recognize this passage and Walter's book as a fictional literary trope. ${ }^{81}$ There is, however, much less agreement on how audiences are meant to imagine the origin of this fictional book. When Walter brings the book "ex Britannia", does he bring it out of Britain or out of Brittany? From the foregoing discussion, it should be apparent how the origin of the book becomes implicated in larger arguments about Geoffrey's ethnicity and his purpose in writing his history. However, another option for the old book's origin exists besides Britain or Brittany. ${ }^{82}$ First, as Paul Russell observes in his contribution to this volume, the $D G B$ positions itself as an extension of classical history, picking up where Dares Phrygius's The Fall of Troy leaves off. Indeed the opening sentence of the Prologue references the title of Dares' work, making this connection clear to aficionados of Trojan history. ${ }^{83}$ But this is not the only reference to Dares. In fact, the passage in which Walter presents

79 See Jones's contribution to this volume, as well as Guy's Welsh reception article.

8o DGB, Prologus, 2.7-12: "Talia michi et de talibus multociens cogitanti optulit Walterus Oxenefordensis archidiaconus, uir in oratoria arte atque in exoticis hystoriis eruditus, quendam Britannici sermonis librum uetustissimum qui a Bruto primo rege Britonum usque ad Cadualadrum filium Caduallonis actus omnium continue et ex ordine perpulcris orationibus proponebat."

81 For some studies of this trope in the 12th century, see: F. Wilhelm, "Antike und Mittelalter. Studien zur Literaturgeschichte. I. Ueber fabulistische quellenangaben", Beiträge zur Geschichte der deutschen Sprache und Literatur 33 (1908), 286-339; M. Otter, Inventiones: Fiction and Referentiality in Twelfth-Century English Historical Writing, Chapel Hill, 1996, pp. 81-82; S. Harris, The Linguistic Past in Twelfth-Century Britain, Cambridge, 2017, pp. 91-99.

82 I would like to thank Owain Wyn Jones for spurring me to think along these lines.

83 See Russell's contribution to this volume. 
the book he brought "ex Britannia" is explicitly modeled off the introduction of The Fall of Troy. Although it originally was written in Greek, The Fall of Troy circulated widely in western Europe in Latin translation, which was purportedly written by one Cornelius Nepos. ${ }^{84}$ While Geoffrey has embellished his source, a comparison of the two shows that the found book passage in the $D G B$ is indebted to the found book passage in The Fall of Troy:

Cum multa Athenis studiose agerem, inveni historicam Daretis Phrygii, ipsius manu scriptam, ut titulus indicat, quam de Graecis et Trojanis memoriae mandavit. ${ }^{85}$

When I was spending my time in a most studious manner at Athens, I found the history of Dares Phrygius, written by his own hand, just as the title makes clear, which he made to remember the Greeks and the Trojans.

Cum mecum multa et de multis saepius animo reuoluens in hystoriam regum Britanniae inciderem, in mirum contuli quod infra mentionem quam de eis Gildas et Beda luculento tractatu fecerant nichil de regibus qui ante incarnationem Christi inhabitauerant, nichil etiam de Arturo ceterisque compluribus qui post incarnationem successerunt repperissem, cum et gesta eorum digna aeternitate laudis constarent et a multis populis quasi inscripta iocunde et memoriter praedicentur. ${ }^{86}$

While my mind was often pondering many things in many ways, my thoughts turned to the history of the kings of Britain, and I was surprised that, among the references to them in the fine works of Gildas and Bede,

84 For a discussion the existence of the work in Greek, see A. Beschorner, Untersuchungen zu Dares Phrygius, Tübingen, 1992, pp. 231-43.

85 Dares Phrygius, The Fall of Troy Prologus, ll. 1-4, ed. F. Meister, Daretis Phrygii. De excidio Troiae historia, Leipzig, 1873, p. 1. The lack of a modern edition of The Fall of Troy has perhaps rendered Geoffrey's indebtedness to Dares slightly more difficult to detect. Meister's edition begins "Cum multa ago Athenis curiose". However, I have chosen to follow the reading witnessed in several of the earliest British manuscripts; for the English and Welsh reception of Dares, see L.F. D'Arcier, Histoire et Géographie d'un Mythe: La Circulation des Manuscrits du De Excidio Troiae De Darès le Phrygien (viii ${ }^{e}-x v^{e}$ siècles), Paris, 2006, pp. 401-23 and pp. 402-03 for a list of British manuscripts. Of the eighteen British manuscripts from the 11th century through the 13th, seven (including the earliest two British witnesses) contain the reading "studiose agerem" or its close variant "studiosissime agerem"; see D’Arcier, Histoire et Géographie d'un Mythe, p. 433, n. 7. See also First Variant Version, ed. Wright, p. xc.

$D G B$, Prologus 1.1-6. 
I had found nothing concerning the kings who lived here before Christ's Incarnation, and nothing about Arthur and the many others who succeeded after it, even though their deeds were worthy of eternal praise and are proclaimed by many people as if they had been entertainingly and memorably written down.

First of all, both passages appear at the very beginning of the work. Geoffrey, moreover, has kept some of the syntax of the first sentence of his source, though he has added many details in additional clauses: Both passages begin with a cum clause and an imperfect verb, and both have multa toward the beginning of the sentence. (As Russell shows in his chapter, this type of half-citation is a hallmark of Geoffrey's style). Both Cornelius and Geoffrey are involved in studious activity: Geoffrey ponders the history of British kings, while Cornelius studies at Athens. Both Cornelius and Geoffrey claim to be translating newly discovered histories that aim to set the historical record straight. ${ }^{87}$ They both pause to reflect on the nature of translation into Latin: Cornelius announces that he has neither added nor omitted anything to his source and that his translation will be straightforward. ${ }^{88}$ Geoffrey, too, claims that his work will be in a simple style, with no rhetorical embellishments. ${ }^{89}$ And they both place their work in opposition to more established and canonical sources. Cornelius offers an alternative to Homer, while Geoffrey suggests that Bede and Gildas do not have the full story either. ${ }^{90}$ In writing his revisionist account of British history, Geoffrey followed Cornelius's discovery of the revisionist account of Trojan history.

Given this, the imagined source of Geoffrey's British book becomes clearer. Cornelius claims to have found historicam Daretis Phrygii, ipsius manu scriptam, "the history of Dares Phrygius, written by his own hand". Importantly, the copy that Cornelius is translating from is Dares' own, from the ancient past. These few words are important for Cornelius because he directly opposes the authority of Dares, who lived and fought in the Trojan war, to that of Homer, who was

87 Cornelius phrases his challenge as a rhetorical question to readers. Dares Phrygius, The Fall of Troy Prologus, ll. 10-16, ed. Meister, p. 1: "utrum magis verum esse existiment, quod Dares Phrygius memoriae commendavit, qui per id tempus ipsum vixit et militavit, quo Graeci Troianos obpugnarent; anne Homero credendum, qui post multos annos natus est, quam bellum hoc gestum est", "whether they judge what Dares Phrygius passed down to be more truthful - he lived and fought during the very time when the Greeks assailed Troy - or if they should believe Homer, who was born many years after the war had been waged."

88 Dares Phrygius, The Fall of Troy Prologus, ll. 4-10, ed. Meister, p. 1.

$89 D G B$, Prologus 2.12-17.

$90 \quad$ See note 86 above. 
born much later - an eyewitness account versus Homer's poetic retelling. This small detail also accords with the way other uses of this trope function in the late classical world - the book miraculously survives from an antique past. ${ }^{91}$ Indeed, other 12th century examples, many of which are indebted to Geoffrey, also imagine that their found books have withstood the wear of time. ${ }^{92}$ In other words, these found books are not copies of copies; they are thought to be authentic artifacts from the past, contemporaneous with the events described therein. The "Britannia" that produced Geoffrey's book is neither Wales/Britain nor Brittany, but the Britannia that Geoffrey's history describes - the famed ancient kingdom over which Arthur and other kings ruled. That is, after all, why Geoffrey mentions that the book is uetustissimus, "very old"; Walter's book has survived from that fabled past to Geoffrey's own day. ${ }^{93}$ The Britannia of the $D G B$, a sovereign kingdom with a single crown, ruled by the native Britons, is the same as imagined by contemporary Welsh historians. ${ }^{94} \mathrm{~A}$ book surviving from that cherished period would electrify Geoffrey's historically-minded Welsh contemporaries. That is, after all, exactly what happened.

91 S. Merkle, "Telling the True Story of the Trojan War: The Eyewitness Account of Dictys of Crete", in J. Tatum (ed.), The Search for the Ancient Novel, Baltimore, 1994, pp. 183-96; id., "The Truth and Nothing but the Truth: Dictys and Dares", in G.L. Schmeling (ed.), The Novel in the Ancient World, Leiden, 1996, pp. 563-80; K. Ní Mheallaigh, "The 'Phoenician Letters' of Dictys of Crete and Dionysius Scytobrachion", The Cambridge Classical Journal $5^{8}$ (2012), 181-93. I would like to thank Joseph Howley for providing me with these references.

92 Gesta abbatum monasterii Sancti Albani, a Thoma Walsingham, regnante Ricardo Secundo, ejusdem ecclesice prcecentore, compilata, ed. H.T. Riley, London, 1867-69, pp. 26-27; The Anglo-Saxon Chronicle: a Collaborative Edition. Vol. 7, MS. E, ed. S. Irvine, Cambridge, 2004, s.a. 963 , pp. 57-58 (see pp. xciv-xcvi for a discussion of the 12th-century interpolation of the miraculous discovery of the "writes"); J. Byron Smith, Walter Map and the Matter of Britain, Philadelphia, 2017, pp. 166-67.

93 At the end of the history, Geoffrey warns his peers to stay silent on the matters of ancient British history, "since they don't possess that book in the British language which Walter the archdeacon of Oxford brought from Britannia ...", "cum non habeant librum illum Britannici sermonis quem Walterus Oxenefordensis archidiaconus ex Britannia aduexit ..." (translation mine). Reeve translates "ex Britannia aduexit" as "carried out of Brittany", but I would suggest that "ex" here is being used to indicate the source of the book, and that by "brought out of Britannia" Geoffrey asks us to imagine Walter recovering the book from antiquity. See $D M L B S$, s.v. ex, def. 6. Of course, Geoffrey could also be imagining a different account of textual transmission at the end of the $D G B$; he does, indeed, seem to delight in ambiguity of this sort.

94 Roberts, "Sylwadau", pp. 139-45; id., "Geoffrey of Monmouth and the Welsh Historical Tradition", Nottingham Mediaeval Studies 20 (1976), 29-40. The idea of an ancient, unified British kingdom with a king ruling from London also existed in Welsh law; see R.C. Stacey, Law and the Imagination in Medieval Wales, Philadelphia, 2018, pp. 29-55, esp. pp. 34-35. 
The Welsh accepted Geoffrey, or at least his work, as their own. Four 13thcentury Welsh translations of Geoffrey's $D G B$ exist, and more appeared in the following centuries. These translations tend to be on the faithful side, though the only English translation available for a modern audience is the highly idiosyncratic Cotton Cleopatra version, which has given non-Welsh readers the unfortunate impression that the Welsh needed to drastically alter Geoffrey's text to make it palatable; they did not. ${ }^{95}$ Moreover, Geoffrey had a pervasive influence on Welsh literature which begins to appear almost immediately after his work circulated. One Welshman, Madog of Edeirnion, produced his own Latin recension of the $D G B$, and provided a prefatory poem that is one of the few surviving direct commentaries on Geoffrey's work produced by the medieval Welsh. ${ }^{96}$ For Madog, Geoffrey's history is nothing less than dulcia, "sweets", to Welsh readers, providing nourishment and pleasure. ${ }^{97}$ Similarly, it would seem that the redactor of the First Variant Version also recognized that the $D G B$ could be read as pro-Welsh, and they perhaps even grasped the danger it posed for accepted English historiography, since one of its central adjustments is to make Geoffrey's history fall into line with other English historical sources. ${ }^{98}$ Overall, the zeal with which the Welsh took to Geoffrey's history led John Gillingham to observe that "no medieval Welshman made the mistake of thinking Geoffrey anti-Welsh." 99 Those elements in Geoffrey's work that have made modern scholars suspect that it does not support Welsh interests - its Breton favoritism and its ending - seem not to have troubled the medieval Welsh in the least.

Another possibility is that Geoffrey's stance in the $D G B$, or even perhaps in his own life, is one of studied ambiguity, a perspective that other writers from the March of Wales, the borderlands between Wales and England, also adopted. ${ }^{100}$ Indeed, he is typically grouped with two other 12th-century Latin

Bruty Brenhinedd: Cotton Cleopatra Version, ed. and trans. J.J. Parry, Cambridge, MA, 1937.

96 The poem appears in Cardiff, Central Library, 2.611, fols. 9v-1or, and was copied into Cambridge, Corpus Christi College, 281. For the edition, see Geoffrey of Monmouth, De gestis Britonum, ed. J. Hammer, Geoffrey of Monmouth. Historia regum Britanniae. A variant version edited from manuscripts, Cambridge, MA, 1951, p. 18.

97 Geoffrey of Monmouth, De gestis Britonum, ed. Hammer, p. 18, l. 24.

98 R.W. Leckie, Jr., The Passage of Dominion: Geoffrey of Monmouth and the Periodization of Insular History in the Twelfth Century, Toronto, 1981; First Variant Version, ed. Wright, pp. lxx-lxxviii.

99 Gillingham, "Context and Purposes", p. 31.

100 For Gerald of Wales, see R. Bartlett, Gerald of Wales, 1146-1223, Oxford, 1982, pp. 16-29 and J.J. Cohen, Hybridity, Identity, and Monstrosity in Medieval Britain: On Difficult Middles, New York, 2006, pp. 77-108. For Walter Map, see J. Byron Smith, Walter Map, pp. 11-28. For Geoffrey's own ambiguity, see Otter, Inventiones. 
writers from the Anglo-Welsh borderlands, forming a trio of Marcher writers whose names all happen to begin with the letter $g$ : Geoffrey of Monmouth, Gerald of Wales, and Walter Map. All three of these authors engage with Wales and its past in ways that are not easily classifiable. At times, they seem to admire aspects of the Welsh, at others, they denigrate them, and elsewhere they seem to take great joy in explaining the Welsh for a wider audience. In spite of the similarities, Geoffrey's intellectual project remains far different from the other two. His interest in British history is deeper and, in actuality, more serious than Gerald's, whose many talents were often self-serving, and Walter's, who had no aspirations to write something that could pass for serious history. In Welsh matters, if Walter is typically thought of as a brilliant anecdotalist and Gerald as a crafty personal propagandist and sly ethnographer, then Geoffrey of Monmouth might be said to be - paradoxically - the author of both the master narrative and the counter narrative of Welsh history, to use two important terms from postcolonial studies. He provided the Anglo-Norman elite with a master narrative that was used to justify the subjugation of Wales, while at the same time he gave the Welsh an illustrious national pedigree that contained within it the possibility of future glories.

If Geoffrey's intention was indeed to play both sides as a Marcher might, to be both Welsh and Anglo-Norman (as Monmouth itself was), then he succeeded tremendously, since current scholarly opinion of his work is as varied as its medieval British reception. The following essays bear out this ambiguity, especially with regard to Geoffrey's "British book", his ethnicity, and his political leanings. In these matters, we have preferred to let the medley of scholarly opinion stand in the open, rather than hide disagreement through editorial fiat. This policy, however, means that several authors, though they seldom agree, address the same passages and problems. Given the variety that these interpretations bring to the volume, we hope that readers approach these occasional repetitions with forgiving eyes.

Finally, like many popular authors, a few erroneous traditions have arisen about Geoffrey. The most egregious, and interesting, is found in the socalled Aberpergwm Brut, a product of Edward Williams (better known as Iolo Morganwg). ${ }^{101}$ Iolo was, among other things, a brilliant forger of early Welsh material, and in his Aberpergwm Brut one can see his inventive mind at work:

In the same year, Geoffrey ab Arthur, the family priest of William ab Rhobert, became bishop, but, before he could enter into his office, he

101 For Iolo's forgeries, see M.A. Constantine, The Truth against the World: Iolo Morganwg and Romantic Forgery, Cardiff, 2007. 
died in his house in Llandaff, and he was buried in the church there. He was a man whose equal in learning, knowledge, and every divine virtue could not be found. He was the foster son of Uchtryd, the archbishop of Llandaff, and his nephew on his brother's side, and for his learning and knowledge he was given the archdeaconry in St Teilo's in Llandaff, where he was the teacher of many scholars and princes. ${ }^{102}$

But this is a mess of lies. ${ }^{103}$ Somewhat more credible is the occasional suggestion that Geoffrey was responsible for the Book of Llandaff, a gospel book that also contains saints' lives and charters and other material about the history of southeastern Wales, much of it of debatable authenticity. ${ }^{104}$ While few scholars today would attribute the Book of Llandaff to Geoffrey, the identification is in truth not so far afield, and it sits uncomfortably here in the same paragraph as Iolo Morganwg's brazen forgery. Geoffrey's supposed authorship of the book is based on some real similarities. Both works show skill in researching and manipulating Welsh historical sources, and both demonstrate a conspicuous ingenuity when it comes to crafting a vision of the past. Indeed, Geoffrey knew material in the Book of Llandaff, but he did not follow it, and he occasionally ridicules the diocese's pretentions in his own work. ${ }^{105}$ For this reason, it seems highly unlikely that he had a hand in the Book of Llandaff, though both he and its authors were involved in the same project of pasting together historical sources to create a coherent narrative of the British past.

Even without Iolo Morganwg's romantic biography, modern readers who are approaching Geoffrey and his work for the first time might be tempted to classify Geoffrey as an eccentric, even exotic, figure. After all, a mysterious writer

102 The Myryrian Archaiology of Wales, ed. O. Jones, E. Williams, and W.O. Pughe, 3 vols., Denbigh, 1801-07, vol. 2, p. 566: "Yn yr un flwyddyn, y gwnaethpwyd Galffrai ab Arthur (offeiriad Teulu Wiliam ab Rhobert) yn Escob, eithr cyn ei fyned yn ei Ansawdd efe a fu farw yn ei Dy yn Llan Dâf, ac a cladded yn yr Eglwys yno. Gwr ydoedd ni chaid ei ail am ddysg a gwybodau, a phob campau dwyfawl. Mab Maeth oedd ef i Uchtryd Archescob Llan Daf, a nai mab brawd iddaw, ac am ei ddysg a'i wybodau y doded arnaw Febyddiaeth yn Eglwys Teilaw yn Llan Daf lle y bu ef yn Athraw llawer o ysgolheigion a phendefigion." Translation mine.

103 See J.E. Lloyd, "Geoffrey of Monmouth", pp. 462-64.

104 The Text of the Book of Llan Dâv: Reproduced from the Gwysaney Manuscript, ed. J.G. Evans and J. Rhŷs, Oxford, 1893, pp. xviii-xxvii; C. Brooke, "The Archbishops of St Davids, Llandaff, and Caerleon-on-Usk", in N.K. Chadwick et al. (eds.), Studies in the Early British Church, Cambridge, 1958, pp. 201-42 (repr. in The Church and the Welsh Border in the Central Middle Ages, ed. D.N. Dumville (Studies in Celtic History, 8), Woodbridge, 1986, 16-49); Roberts, "Sylwadau", pp. 129-30; VM, pp. 31-33.

105 For Geoffrey's knowledge of the Book of Llandaff, see Guy's contribution to this volume. 
who called the borderlands home, who possessed deep learning, and who trafficked in ancient stories of a forgotten past certainly exercises a pull upon the imagination. As attractive as that portrait is, Geoffrey is better understood as a natural product of multicultural and multilingual 12th-century Britain. Indeed, as Geoffrey himself wrote, the Britain of his day was "inhabited by five peoples, the Normans, the Britons, the Saxons, the Picts and the Scots". ${ }^{106}$ Even this description falls short of the actual cultural heterogeneity of 12th-century Britain, since Geoffrey here is constrained by his stylized adaptation of Bede and he omits Breton immigrants, Flemish settlers, and Jewish inhabitants, to name just a few. Far from being an outlier, his mélange of Welsh, English, and Norman influences shows him to be part of the mainstream of the intellectual culture of his day. From Monmouth to Oxford, dying with his eyes turned toward a bishopric in northern Wales, no doubt still turning over the ancient British past in his mind, Geoffrey embodies the complex, often vexed, cosmopolitanism of his day. In turn, we hope that the various essays presented in this volume, written by scholars at all stages of their careers and from several disciplines, do justice to Geoffrey's own diverse influences and inspirations.

$106 D G B$, i.5.42-44: “... quinque inhabitatur populis, Normannis uidelicet atque Britannis, Saxonibus, Pictis, et Scotis". 